\title{
EFFECTS OF IGNEOUS INTRUSION ON THE MINERALOGICAL CONTENT OF IRATI Formation, Paraná Basin, in SAPopema (PR), Southern Brazil
}

\section{Werlem Holanda ${ }^{1 *}$, Anderson Costa dos Santos ${ }^{1}$, Camila Cardoso Nogueira ${ }^{1}$, Luiz Carlos

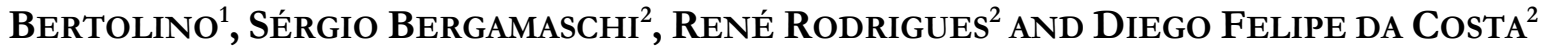

1 Universidade do Estado do Rio de Janeiro (UERJ), Faculdade de Geologia, Departamento de Mineralogia e Petrologia Ígnea. Rua São Francisco Xavier. 524 - 4ªndar/bloco A, 20550-900, Rio de Janeiro (RJ), Brazil

2 Universidade do Estado do Rio de Janeiro (UERJ), Faculdade de Geologia, Departamento de Estratigrafia e Paleontologia. Rua São Francisco Xavier. 524 - $2^{\circ}$ andar/bloco A, 20550-900, Rio de Janeiro (RJ), Brazil

*CORRESPONDING AUTHOR, werlemholanda@hotmail.com

Received on 14 August 2019

Received in revised form on 25 September 2019

Accepted on 28 September 2019

Editor: Maria Virginia Alves Martins, Universidade do Estado do Rio de Janeiro, Brazil

\section{Abstract}

Igneous intrusions in sedimentary basins are commonly related with mineralogical association changes in host-rock. At Sapopema region (Paraná State, southern Brazil), an extensive diabase sill (associated to Serra Geral Formation) was emplaced in pelitic-carbonate succession during postTriassic. The sedimentary host-rock association includes mostly shale, siltstone and carbonate of the Permian Irati Formation. X-ray diffraction (XRD), scanning electron microscopy (SEM) and energy dispersive spectroscopy (EDS) data revealed that heat transfer was not enough to cause modifications in mineral assemblage of the Taquaral
Citation:

Holanda, W., Costa dos Santos, A., Nogueira, C.C., Bertolino, L.C., Sérgio Bergamaschi, Rodrigues, R., Felipe da Costa, D., 2019. Effects of Igneous Intrusion on the Mineralogical Content of Irati Formation, Paraná Basin, in Sapopema (PR), Southern Brazil. Journal of Sedimentary Environments, 4 (3): 350-360.

\section{Introduction}

Igneous intrusions are common in many sedimentary basins worldwide (e.g. Jones et al., 2007; Thomaz-Filho et al., 2008; Delpino and Bermúdez, 2009; Miranda et al., 2016), including the intracratonic Paleozoic Paraná Basin (southern Brazil; Fig. 1). During magmatic intrusion, temperatures above $1100{ }^{\circ} \mathrm{C}$ generally cause melting and the sills can affect the sedimentary host rock by developing contact metamorphic aureoles (e.g., Jaeger, 1959; Simoneit et al., 1978; Aarnes et al., 2010; Senger et al., 2014). Heat transfer related to igneous intrusions in sedimentary basins will produce variations in rock properties, such as changes in mineralogy, organic geochemistry, and rock microstructure (Senger et al., 2014; Li et al., 2016; Illgen et al., 2017).

In its stratigraphic record, the Paraná Basin exhibits igneous rocks related to the rupture of the Gondwana

Supercontinent, which gave rise to the opening of the Atlantic Ocean ca. $120 \mathrm{Ma}$ (Mizusaki and Thomaz Filho, 2004). The Serra Geral Formation comprises a thick pile of lava flows, which can reach thicknesses of $2.000 \mathrm{~m}$ in some regions (Milani and Zalan, 1999). This formation is characterized by a network of dikes, cutting the entire Paleozoic-Mesozoic sedimentary succession, and multiple diabase sills that intrude into the stratification planes of Paleozoic sediments, preferentially along the Irati Formation horizons (Mizusaki and Thomaz Filho, 2004).

The effects of magmatic intrusions on physical properties and evolution of organic matter in shales have received much attention in the Paraná Basin (Milani, 1997; Milani and Zalán, 1999; Araújo et al., 2000; Correa and Pereira, 2005; Costa et al., 2016, among others). However, few researches have addressed the changes in mineralogical 
content of the Irati Formation (Girardi et al., 1978; dos Anjos et al., 2010). This work describes the impact of igneous intrusion in the Permian Irati Formation, in Sapopema region, and discusses changes in the mineralogical content.

\section{Study Area}

The study area is part of the tectonic-stratigraphic context of the Paraná Basin (Fig. 1), a vast region composed of sedimentary and magmatic rocks, which extends from the southern part of Brazil to Eastern Paraguay and the northeast of Argentina and northwest of Uruguay, covering a total area of approximately 1.4 million square kilometers (Milani, 1997).

Irati Formation (Permian) lies within the tectonic sequence of Gondwana I, corresponding to the basal unit of Passa Dois Group, and is subdivided into the Taquaral (lower) and Assistência (upper) members (Fig. 1). Taquaral Member is composed of grey siltstones and shales with parallel lamination (Santos Neto, 1993). The Assistência Member is composed of bituminous black shales intercalated with cream-colored to grey carbonatic horizons (Hachiro, 1996). According to Schneider et al. (1974), the lithological and paleontological characteristics of Irati Formation indicate, for Taquaral Member, deposition in a marine environment with calm waters, below the level of wave action. For Assistência Member, a shallow marine environment under basin restriction (low circulation and oxygenation), which allowed the deposition of black carbonatic shales, which developed on shelf areas (Araújo et al., 2000).

Costa et al. (2016) demonstrated, through 2D seismic interpretation, that the Irati Formation contains postTriassic, basic igneous bodies, composed of dykes and sill with thicknesses that vary in different parts of the basin. In the study area, the isopach map of Serra Geral Formation shows the occurrence of thick intervals of igneous rocks in contact with Irati Formation (Fig. 2).

\section{Materials and Methods}

X-ray diffraction (XRD), scanning electron microscopy (SEM) and energy dispersive spectroscopy (EDS) analyses were carried out in Irati Formation core samples from the well SP-58- PR (Coordinates Córrego Alegre, Zone 22S: $7383382 \mathrm{~N} / 549372 \mathrm{E})$. This well is located in Sapopema, northeastern Paraná state, and was drilled by the Geological Survey of Brazil (CPRM) in the 1970s.

\subsection{X-ray diffraction (XRD)}

All the preparation procedures for the samples and XRD analyses were carried out in the Laboratório Multiusuários de Caracterização Tecnológica (LMCT) of the Centro de Tecnologia Mineral (CETEM), Rio de Janeiro (Brazil). The XRD method was applied to 16 samples from different depths, encompassing the Taquaral and Assistência members.

Considering the interplanar distances (d) relative to the diffractometric reflections, different mineral species were identified in the $<63 \mu \mathrm{m}$ and $<2 \mu \mathrm{m}$ fractions. Utilizing the powder method, the XRD analyses were carried out in a Bruker-AXS D8 Advance Eco equipment, with $\mathrm{Cu} \mathrm{K} \alpha$ $(40 \mathrm{kV} / 25 \mathrm{~mA})$ radiation.

Randomly oriented samples of whole-rock powders were prepared by filling front-loading XRD mounts (Moore and Reynolds, 1997). The samples were scanned at a rate of $1^{\circ} 2 \theta / \mathrm{min}$ from $5^{\circ}$ to $50^{\circ} 2 \theta$. For the analysis of the oriented samples $(<2 \mu \mathrm{m})$, non-clay minerals were removed through standard chemical treatment, based on Stokes' Law (Moore and Reynolds, 1997). Thus the $<2 \mu \mathrm{m}$ fraction were prepared by air drying a small amount of dispersed suspension on a glass slide. To help identify the clay minerals, ethylene glycol-solvated (12h) samples and samples heated at $510^{\circ} \mathrm{C}$ for $1 \mathrm{~h}$ were also prepared using well known methods (Alves, 1987; Moore and Reynolds, 1997; Martins et al., 2007). Theses samples were scanned from $4^{\circ}$ to $30^{\circ} 2 \theta$.

Qualitative and semiquantitative mineralogical analysis followed the method described by Melo et al. (2018). The qualitative interpretation of the spectrum was performed with a Bruker-AXS Diffrac.EVA 4.0 or 4.1 software and PDF04+ database. The first step was mineral identification, and then the peaks of each mineral were scaled manually to give the best fit to the observed XRD diffraction. The semiquantitative analysis was carried out considering the $\mathrm{X}$ ray powder diffraction and the minerals in the International Centre for Diffraction Data database (ICDD, 2017).

\subsection{Scanning Electron Microscopy (SEM) and Energy Dispersive Spectroscopy (EDS)}

Sample preparation for analysis in the SEM followed the norm established by the Laboratório de Análise Mineralógica of CENPES/PETROBRAS. Based on XRD mineralogical interpretation, four samples were selected to SEM/EDS analyze: first ground, in order to offer a fresh and irregular surface, then; glued to a brass conductive support and; finally covered by a thin layer of goldpalladium with the EMITECH K750X metallizer, to make it electrically conductive. Then, it was glued to an aluminum conducting support and analyzed in the ZEISS EVO LS-15 scanning electron microscope, with images produced by backscattered electrons, operating at high vacuum, at $20 \mathrm{kV}$, and using a working distance of 12.50 $\mathrm{mm}$.

The image produced by backscattered electrons represents, in its shades of grey, the variation of the average atomic composition of the feature that was imaged, 
meaning that materials of heavier atomic weight will produce images in lighter shades of grey, while lower

atomic weight materials will produce darker images.

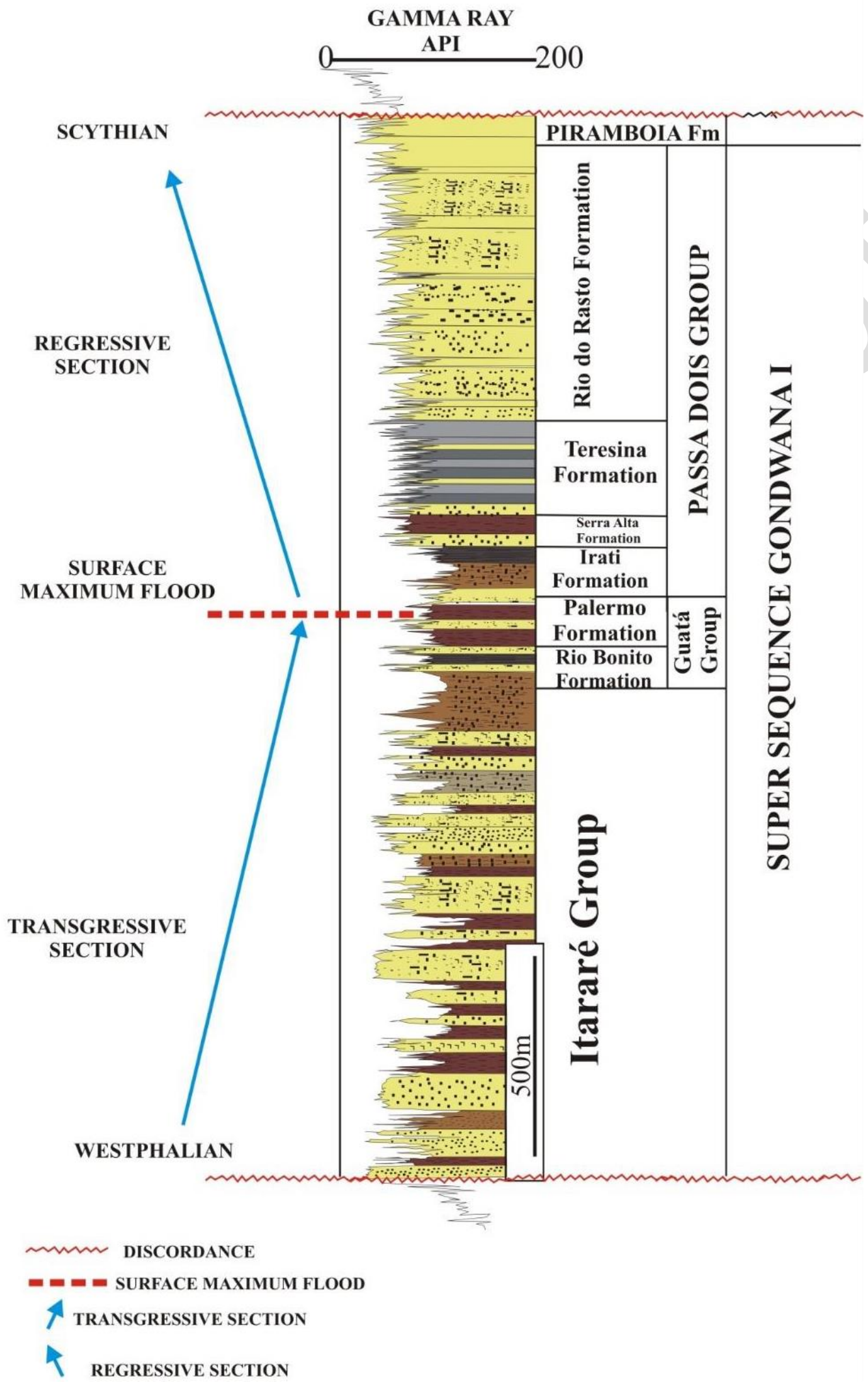

Fig. 1. The stratigraphic lithological pattern of the tectonic sequence Gondwana I, based on the Gama Ray well log (modified from Euzébio et al., 2016). 

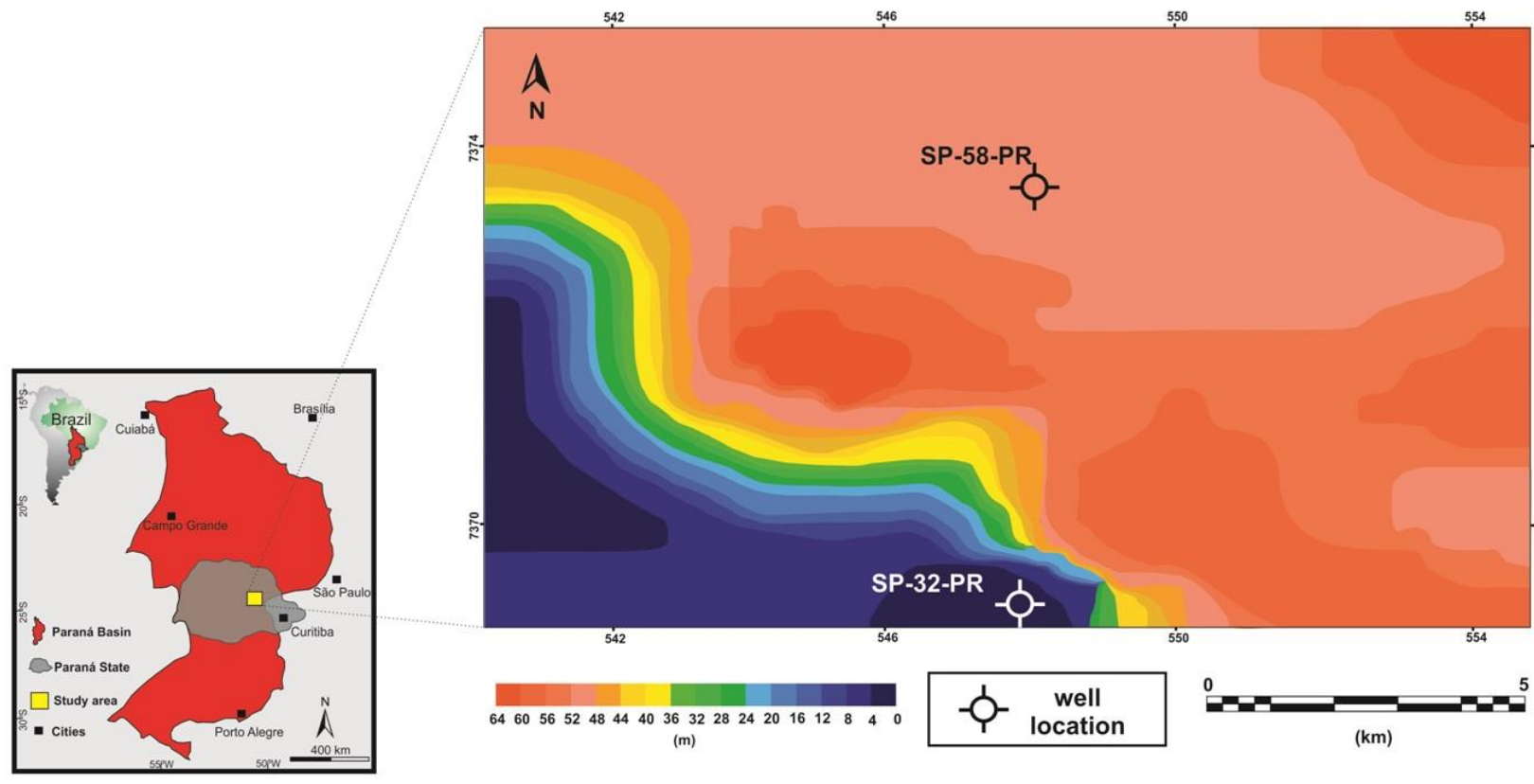

$(\mathrm{km})$

Fig. 2. Location of the study area in Paraná Basin. Isopach map of Serra Geral Formation in the study area, in Sapopema region (PR), southern Brazil. Well SP-58-PR used in the current study and SP-32-PR studied by Holanda et al. (2018).

The EDS microanalyses were obtained with the OXFORD Inca-AZtec Microanalysis System, coupled to the SEM, which provide the compositional

\section{Results}

Based on the interplanar distances (d) of the diffractometric reflections (Tab. 1), the following minerals were identified in the whole rock analysis for well SP-58PR: quartz, albite, muscovite, calcite, dolomite, talc, pyrophyllite and pyrite (Fig. 3).

Tab. 1. Interplanar distance of the minerals interpreted in the current work.

\begin{tabular}{|l|c|c|}
\hline \multicolumn{1}{|c|}{$\begin{array}{c}\text { Phole Rock } \\
\text { (d) }\end{array}$} & $\begin{array}{c}\text { Secondary peaks } \\
\text { (d) }\end{array}$ \\
\hline Calcite & $3.03 \AA$ & $2.09 \AA$ and $2.28 \AA$ \\
\hline Dolomite & $2.88 \AA$ & $1.78 \AA$ and $2.19 \AA$ \\
\hline Muscovite & $3.32 \AA$ & $9.95 \AA$ and $2.57 \AA$ \\
\hline Pyrite & $1.63 \AA$ & $2.70 \AA$ and $2.42 \AA$ \\
\hline Pyrophyllite & $9.2 \AA$ & $4.6 \AA$ and $3.07 \AA$ \\
\hline Albite & $3.17 \AA$ & $3.21 \AA$ and $3.75 \AA$ \\
\hline Quartz & $4.26 \AA$ & $3.34 \AA$ and $1.82 \AA$ \\
\hline Talc & $9.35 \AA$ & $1.53 \AA$ and $4.59 \AA$ \\
\hline
\end{tabular}

The diffractometric reflections interpreted under different conditions (samples without treatment, samples (semiquantitative) tables of the chemical elements identified as oxides (calculated stoichiometrically). The EDS detector does not detect the elements $\mathrm{H}, \mathrm{He}, \mathrm{Li}$ and $\mathrm{Be}$. solvated with ethylene glycol for $12 \mathrm{~h}$ and samples heated to $510^{\circ} \mathrm{C}$ for $1 \mathrm{~h}$ ) indicated the following groups of clay minerals: illite, smectite, chlorite and kaolinite (Tab. 2). The occurrence of kaolinite was limited to the Taquaral Member, along with illite and chlorite, while in Assistência Member, the diffractometric peaks related to illite and smectite were most remarkable (Fig. 3).

Tab. 2. Primary peak of clay minerals under normal conditions $(\mathrm{N})$, solvated with ethylene glycol $(\mathrm{G})$ and heated $(\mathrm{H})$. Modified from Neves (1968) and Albers et al. (2002).

\begin{tabular}{|c|c|c|c|}
\hline Clay minerals & $\begin{array}{c}\mathbf{d}(\AA) \\
\mathbf{N}\end{array}$ & $\begin{array}{c}\mathbf{d}(\AA) \\
\mathbf{G}\end{array}$ & $\begin{array}{c}\mathbf{d}(\AA) \\
\mathbf{H}\end{array}$ \\
\hline Illite & $10 \AA$ & $10 \AA$ & $10 \AA$ \\
\hline Kaolinite & $7 \AA$ & $7 \AA$ & -- \\
\hline Chlorite & $14 \AA$ & $14 \AA$ & $14 \AA$ \\
\hline Smectite & $14 \AA$ & $17 \AA$ & $10 \AA$ \\
\hline
\end{tabular}

Figure 4A shows the general appearance of the sample closest to contact with overlying diabase (approximately 40 $\mathrm{cm}$ from it), with polygons showing the different areas in which chemical analyses were performed with EDS (Table 3) to help identify minerals. 
RESEARCH PAPER
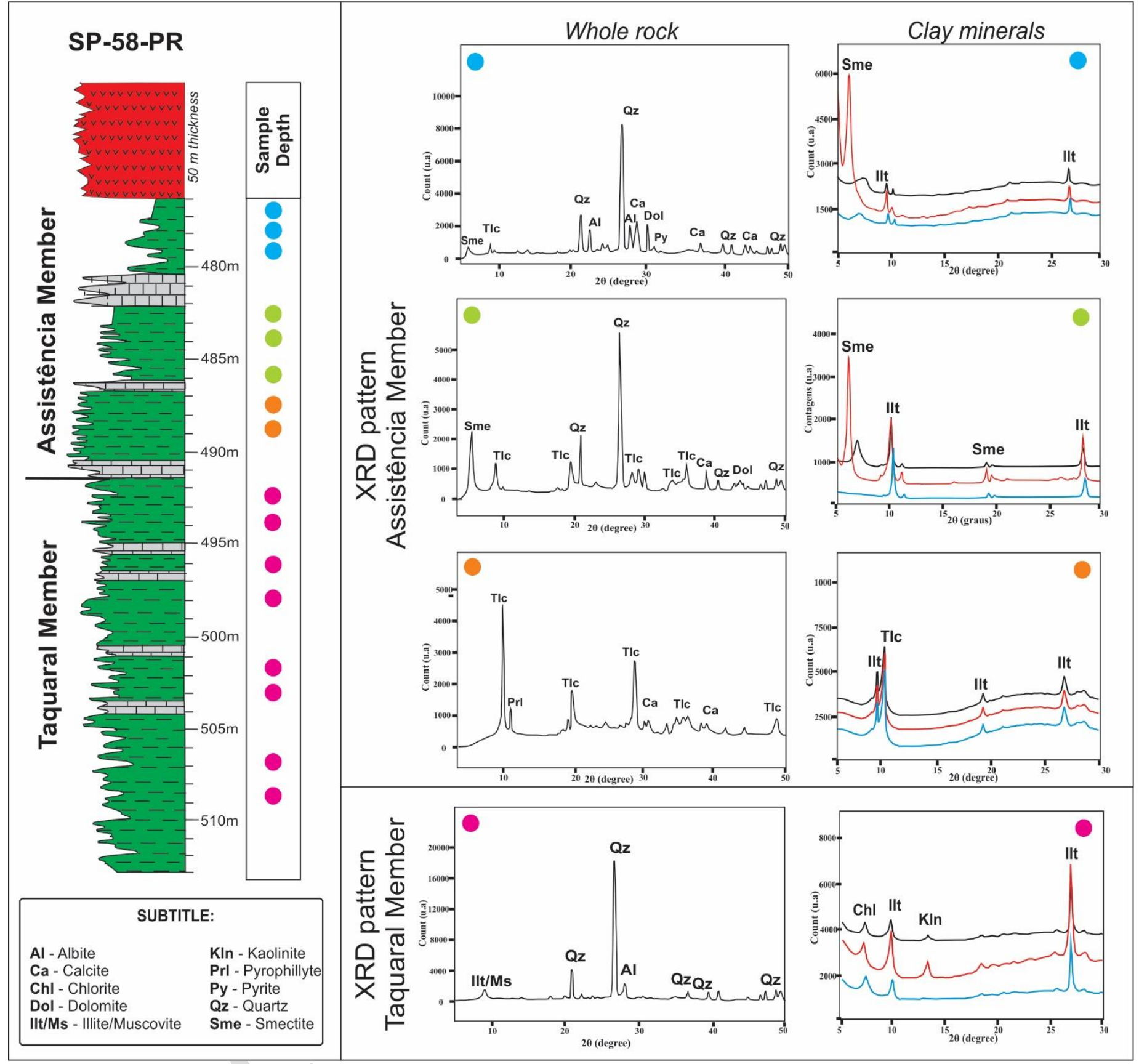

Fig. 3. Whole rock and clay minerals XRD pattern from Taquaral and Assistência Members, in well SP-58-PR.

Tab. 3. Chemical composition, in oxides, of the polygons signed in Figure 2.

\begin{tabular}{|c|c|c|c|c|c|c|c|c|c|c|}
\hline Polygon & $\begin{array}{c}\mathrm{Na}_{2} \mathrm{O} \\
\%\end{array}$ & $\underset{\%}{\mathrm{MgO}}$ & $\underset{\%}{\mathrm{Al}_{2} \mathrm{O}_{3}}$ & $\begin{array}{c}\mathrm{SiO}_{2} \\
\%\end{array}$ & $\begin{array}{c}\mathrm{SO}_{3} \\
\%\end{array}$ & $\begin{array}{c}\mathbf{K}_{2} \mathbf{O} \\
\%\end{array}$ & $\underset{\%}{\mathrm{CaO}}$ & $\underset{\%}{\mathrm{TiO}_{2}}$ & $\begin{array}{c}\mathrm{FeO} \\
\%\end{array}$ & $\begin{array}{c}\text { Total } \\
\%\end{array}$ \\
\hline 1 & & & & 100 & & & & & & 100 \\
\hline 2 & 9.57 & & 19.79 & 68.52 & & 0.62 & 0.57 & & 0.93 & 100 \\
\hline 3 & & & & 99.34 & & & & & 0.66 & 100 \\
\hline 4 & 9.59 & & 19.3 & 65.71 & 2.88 & 0.53 & & & 1.98 & 100 \\
\hline 5 & & & & 100 & & & & & & 100 \\
\hline 6 & & & & 100 & & & & & & 100 \\
\hline
\end{tabular}



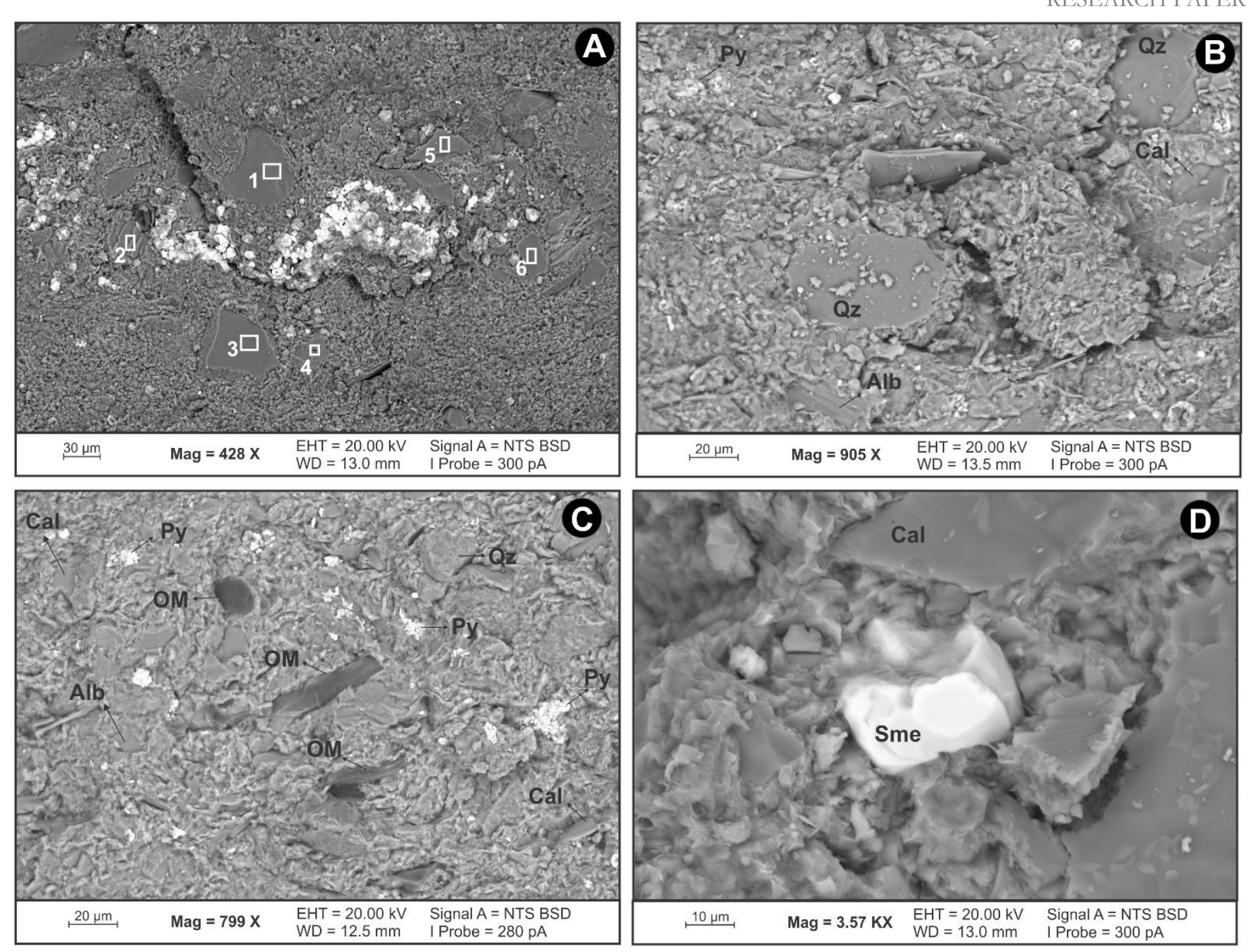

Fig. 4. SEM photomicrographs of sediment samples of the Irati Formation in well SP-58-PR, showing: (A) a general view of a sample of the Assistência Member; (B) quartz (Qz), albite (Alb), calcite (Cal) and pyrite (Py) grains; (C) quartz (Qz), albite (Alb), calcite (Cal), pyrite (Py) grains and organic matter (OM); (D) smectite (Sme) agglutinated flocs.

The correlation between Figure 4 and Table 3 supports the illation that the areas represented by the polygons 1,3 , 5 and 6 represent anhedral quartz crystals, which stand out from the matrix due to their larger size (generally larger than $40 \mu \mathrm{m})$ and because their edges evidence recrystallization. The areas represented by polygon 2 and 4 are plagioclase crystals, which, due to their high $\mathrm{NaO}$ content, should be albite, and also stand out in the rock matrix. The area represented by polygon 7 exhibited a more complex chemical composition, compatible with biotite.

Figures $4 \mathrm{~B}$ and $4 \mathrm{C}$ are 2.0 and 3.8 meters far from the contact with intrusive rocks, respectively. The mineralogy in these intervals is characterized by the presence of quartz, albite, calcite and pyrite. SEM/EDS analyses revealed the occurrence of clay minerals of the smectite group that occur mainly as agglutinated anhedral flocs approximately 2 $\mu \mathrm{m}$ in size (Fig. 4D).
Based on the MEV/EDS analysis (Fig. 5 and Tab. 4) the areas represented by polygons 1, 2, 3, 4, 6, 7, 8 and 10 represent the mineral talc, which seems to be responsible for the sample crenulated texture when observed at micrometric scale (Figs. 5A and 5B). The areas represented by polygons 5, 9, 11 and 12 represent large crystal of calcite (5B), with rhombohedral (5C) and tuberose (5D) habits.

\section{Discussion}

In this study, we have investigated the process of heat transfer from igneous (ca. $50 \mathrm{~m}$ thickness) to host-rock based on the mineralogical content pelitic rocks. Holanda et al. (2018) studied the mineralogical content of the Irati Formation in the Sapopema region, well SP-32-PR (Fig. 1), where the Irati Formation is not in contact with the igneous rock. Table 5 correlates the mineralogical content interpreted in both wells based on XRD patterns. 
Apparently, the heat transfer was not enough to cause modifications in the mineralogical assemblage of the Taquaral Member (quartz + albite + muscovite + illite + kaolinite + chlorite). However, the mineralogical content from Assistência Member presented changes probably caused by the intrusion of the diabase sill.

Through SEM/EDS analyses, crystals with chemical composition compatible with calcite and talc were observed. Dos Anjos and Guimarães (2008) proposed a chemical reaction (1) that would justify the presence of talc and calcite from dolomite and quartz in the northern region of the Paraná Basin:

$$
\begin{aligned}
3 \mathrm{CaMg}\left(\mathrm{CO}_{3}\right)_{2} & +2 \mathrm{SiO}_{2}+2 \mathrm{H}_{2} \mathrm{O} \\
3 \mathrm{CaCO}_{3} & \rightarrow 3 \mathrm{CO}_{2} \uparrow \ldots \ldots \ldots \ldots \ldots \ldots \ldots \ldots \ldots . .(1)
\end{aligned} \rightarrow \mathrm{Mg}_{3} \mathrm{Si}_{2} \mathrm{O}_{5}(\mathrm{OH})_{4}+
$$

Dos Anjos et al. (2010) described talc crystals as a metamorphic mineral according to their coherent scattering domain size values, relative quantities and texture (northern region of the basin). Besides that, the authors noted that metamorphic minerals were parallel to the bedding in the unmetamorphosed rocks but become major components in some layers near the sill where they are randomly oriented with respect to the bedding.

In the Perolândia quarry (northern region of the basin), a 13-m-thick basic sill intrudes black shales and limestones of the Irati Formation. A detailed investigation across the contact between the igneous and the sedimentary rocks revealed that near the contact with the sill, talc and serpentine formed in the limestone, while magnesiumbearing minerals such as pyroxene formed in the black shales. In the same region, Santos et al. (2009) modeled the variation of temperature across the contact zone using a one-dimensional transfer model, concluding that temperature of the sedimentary rocks reached $500^{\circ} \mathrm{C}$ in the vicinity of the contact and then decreased to $200^{\circ} \mathrm{C}$ at a distance of $18 \mathrm{~m}$ from the contact.

Based in thermodynamic model of Berman (1988) and Brady et al. (1998), we propose that stability of the assemblage talc + calcite is limited to temperatures below $\approx 450^{\circ} \mathrm{C}$ and pressure lower than 6 kbar (Fig. 6). Fig. 3 illustrates the presence of this mineral assemblage along 16 m of the Assistência Member thickness.

The analyses performed by XRD indicated diffractometric reflections related to pyrophyllite. Frey (1987) described pyrophyllite in the Helvetic nappes and the Switzerland Prealps. It has been discovered mainly in Jurassic black shale and in Jurassic and Eocene laterites. The mineral distribution pattern strongly suggests that kaolinite + quartz (Fig. 6) provides the starting material for the appearance of pyrophyllite by virtue of the reaction (2):

$\mathrm{Al}_{2} \mathrm{Si}_{2} \mathrm{O}_{5}(\mathrm{OH})_{4}+2 \mathrm{SiO}_{2} \rightarrow \mathrm{Al}_{2} \mathrm{Si}_{4} \mathrm{O}_{10}(\mathrm{OH})_{2}+\mathrm{H}_{2} \mathrm{O} \ldots \ldots \ldots \ldots$ (2)

Fluid inclusion studies by Mullis (1979) have documented methane-rich fluids at such very low metamorphic grade, derived from the cracking of organic material. Assuming constant temperature and fluid pressure, an assemblage containing kaolinite + quartz + organic matter could have reacted to yield pyrophyllite. According to Euzébio et al. (2016) and Holanda et al. (2018), TOC ranges between 0.25 and $2.11 \%$ for the Assistência Member in SP-58-PR.

\begin{tabular}{|c|c|c|c|c|c|c|c|c|c|}
\hline Polygon & $\begin{array}{c}\mathrm{Na}_{2} \mathrm{O} \\
\%\end{array}$ & $\underset{\%}{\mathrm{MgO}}$ & $\begin{array}{c}\mathrm{Al}_{2} \mathrm{O}_{3} \\
\%\end{array}$ & $\begin{array}{c}\mathrm{SiO}_{2} \\
\%\end{array}$ & $\begin{array}{c}\mathrm{SO}_{3} \\
\%\end{array}$ & $\begin{array}{c}\mathbf{K}_{2} \mathbf{O} \\
\%\end{array}$ & $\begin{array}{c}\mathrm{CaO} \\
\%\end{array}$ & $\begin{array}{c}\mathrm{FeO} \\
\%\end{array}$ & $\begin{array}{c}\text { Total } \\
\%\end{array}$ \\
\hline 1 & 1.11 & 30.44 & 2.95 & 62.11 & 1 & & 2.39 & & 100 \\
\hline 2 & 1.14 & 31.09 & 2.84 & 61.24 & & & 2.38 & 1.31 & 100 \\
\hline 3 & & 26.72 & 3.42 & 61.97 & & & 2.9 & 4.98 & 100 \\
\hline 4 & 1.13 & 27.61 & 3.4 & 64.83 & & & 1.15 & 1.88 & 100 \\
\hline 5 & & & & & & & 100 & & 100 \\
\hline 6 & 0.58 & 15.34 & 0.92 & 79.58 & & & 1.29 & 1.32 & 100 \\
\hline 7 & 0.85 & 25.16 & 210 & 69.59 & & & 0.97 & 1.34 & 100 \\
\hline 8 & 0.73 & 25.5 & 1.67 & 69.52 & & & 1.16 & 1.42 & 100 \\
\hline 9 & 1.08 & 1.57 & & 3.08 & & & 94.27 & & 100 \\
\hline 10 & 2.71 & 31.22 & 6.21 & 56.54 & & & 1.72 & 1.62 & 100 \\
\hline 11 & & & & & & & 100 & & 100 \\
\hline 12 & & & & 0.95 & & & 99.05 & & 100 \\
\hline
\end{tabular}

Tab. 4. Chemical composition, in oxides, of the polygons in Figure 3. 

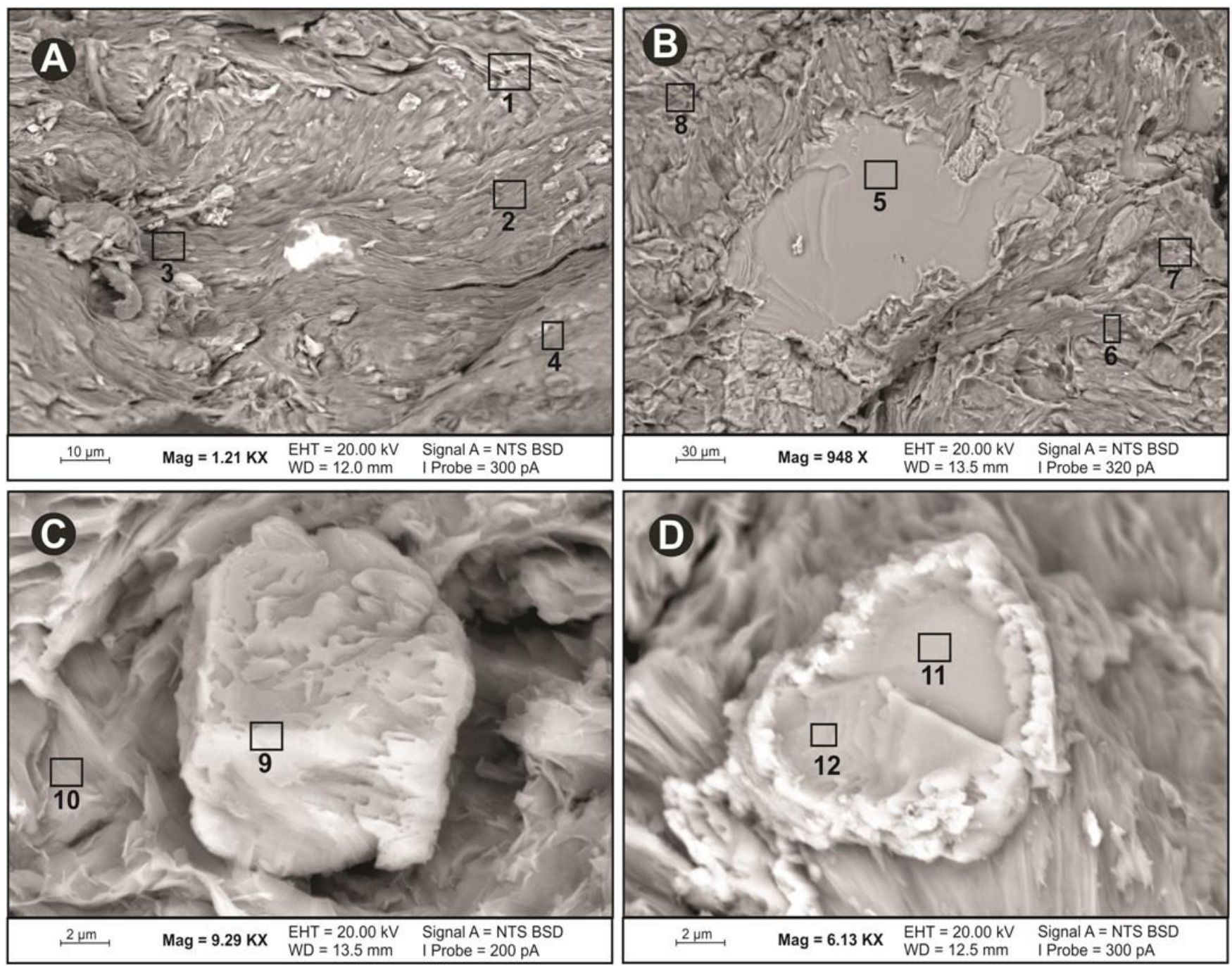

Fig. 5. SEM photomicrographs of the sample at $486.0 \mathrm{~m}$ of the Irati Formation in well SP-58-PR, showing: (A) crenulated texture of the rock, (B) crystal of calcite with rhombohedral (C) and tuberose (D) habits.

Tab. 5. Comparison of the mineralogical content of Irati Formation in the Sapopema region.

\section{SP-58-PR}

Lithostratigraphy (with thermal influence from sill) (without thermal influence from sill)

\begin{tabular}{|c|c|c|c|c|}
\hline & Whole rock & Clay Minerals & Whole rock & Clay Mineral \\
\hline \multirow{8}{*}{ Assistência } & Quartz & Illite & Quartz & Illite \\
\hline & Albite & Smectite & Albite & Smectite \\
\hline & Muscovite & Talc & Muscovite & Kaolinite \\
\hline & Pyrite & Pyrophyllite & Pyrite & - \\
\hline & - & 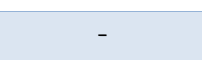 & Analcime & - \\
\hline & - & - & Gypsite & - \\
\hline & Dolomite & - & Dolomite & - \\
\hline & Calcite & - & Calcite & - \\
\hline \multirow{3}{*}{ Taquaral } & Quartz & Illite & Quartz & Illite \\
\hline & Albite & Kaolinite & Albite & Kaolinite \\
\hline & Muscovite & Chlorite & Muscovite & Chlorite \\
\hline
\end{tabular}


Alves and Rodrigues (1985) studied the effect of igneous intrusions on the mineralogy of the Devonian shale of the Amazonas Basin. Based on Winkler (1976), the authors proposed that pyrophyllite formation occurred from kaolinite + quartz reaction at temperature below $400^{\circ} \mathrm{C}$.

The XRD and SEM analyses pointed to the presence of clay minerals of the smectite and illite groups in Assistência Member, while in Taquaral Member, besides illite, diffractometric reflections consistent with chlorite and kaolinite are observed. The relation between the thermal evolution of pelitic rocks and the occurrence of different types of clay minerals was the subject of several prior research works (Winkler, 1976; Frey, 1987; Weaver, 1989; Meunier, 2005).

There is a mineralogical order that reflects thermal evolution conditions ranging from smectite to mixed-layer smectite/illite to illite, where the smectite is associated with lower temperatures and the illite with higher temperatures. Despite the thermal halo generated by the contact with the overlying diabase, it is not possible to discern an ordering of the clay minerals in well SP-58-PR. The reaction of smectite to illite has been used as an empirical geothermometer or thermal maturity indicator in a wide range of geologic environments (e.g., Hoffman and Hower, 1979).

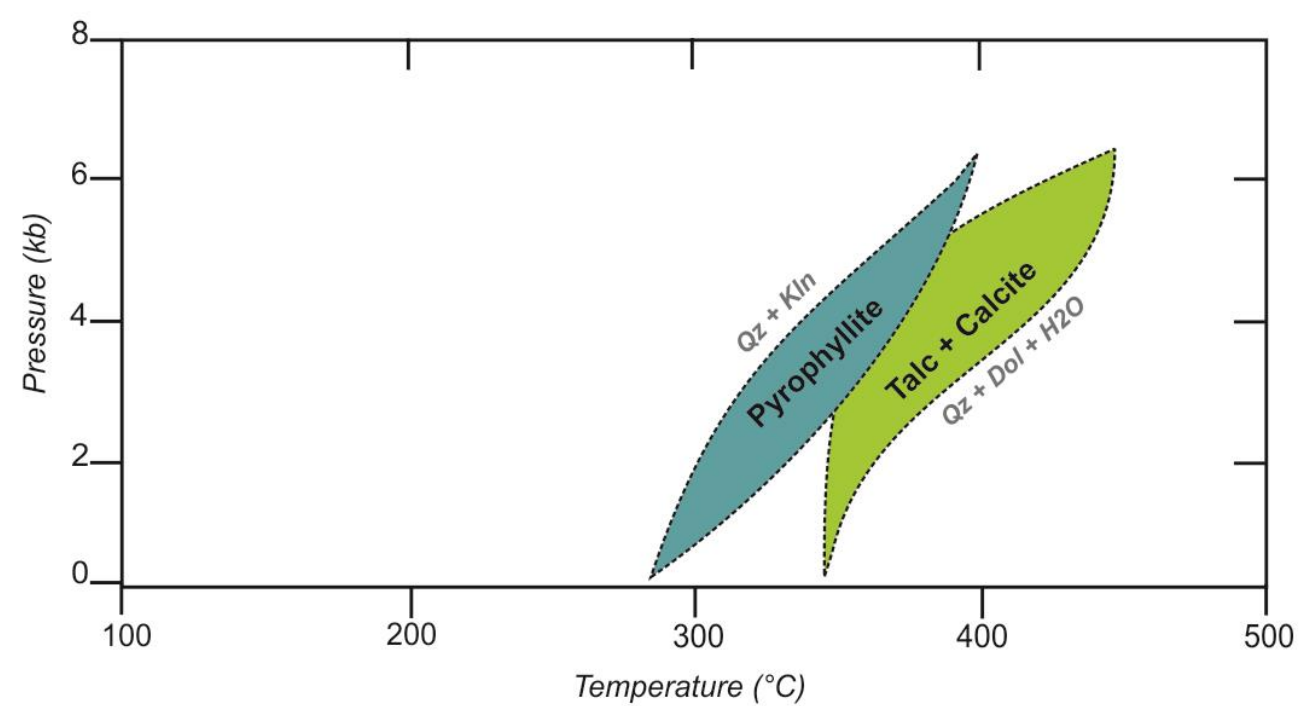

Fig. 6. Thermodynamic equilibrium curve of the pyrophyllite (Winkler, 1976) and talc (Brady et al., 1998).

Some studies have demonstrated that the illitization reaction is more complex than previously thought and that several chemical and physical variables may affect the rate of reaction (Inoue et al., 1988; Whitney and Northrop, 1988). Although a sixth-order kinetic expression effectively models of the overall reaction, the reaction undoubtedly represents a series of poorly understood processes which together constitute the total reaction (Pytte and Reynolds, 1989).

The results predicted by most published heat transfer models of igneous intrusions can match well with some geothermometers such as vitrinite reflectance and fluid inclusions. This partly attests the reliability of those models for reconstructing the thermal evolution of host rocks (Galushkin, 1997; Wang et al., 2010, 2011). Therefore, based on the study of chemical reactions and mineral modifications it is very difficult to stablish the overall heat transfer model of igneous intrusions within sedimentary layers. For that other analytical techniques besides mathematical models to get a more accurate result are required.

\section{Conclusion}

The investigation based on XRD and SEM/EDS analyses indicates that the mineralogical changes in pelitic rocks of Irati Formation were induced by thermal effects of diabase sill. However, these changes are restricted to the Assistência Member.

Talc and calcite were formed due to the reaction between dolomite and quartz, limited to temperatures below about $450^{\circ} \mathrm{C}$. This assemblage was found along $16 \mathrm{~m}$ of Assistência Member thickness. However, pyrophyllite can be considered as product of the reaction between kaolinite and quartz limited to temperatures below $400^{\circ} \mathrm{C}$. XRD pattern of these samples were restricted to samples farthest from the diabase sill.

\section{Acknowledgements}

The authors thank all the staff of the Laboratório de Pesquisa e Desenvolvimento em Exploração e Produção (PDE) of the Gerência de Integração Rocha-Perfil-Sísmica (IRPS) of CENPES/Petrobras, where the SEM/EDS analyses were carried out, and all the staff of Laboratório de Estratigrafia Química e Geoquímica Orgânica (LGQM/UERJ) of the Rio de Janeiro State University. 


\section{References}

Aarnes, I., Svensen, H., Connolly, J.A.D., Podladchikov, Y.Y., 2010. How contact metamorphism can trigger global climate changes: Modeling gas generation around igneous sills in sedimentary basins. Geochimica et Cosmochimica Acta 74, 7179-7195. https://doi.org/10.1016/j.gca.2010.09.011

Albers, A.P.F., Melchiades, F.G., Machado, R., Baldo, J.B., Boschi, A.O., 2002. Um método simples de caracterização de argilominerais por difração de raios X. Cerâmica 48, 305-308.

Alves, D.B., 1987. Desenvolvimento da metodologia de preparação de amostras para análise difratométrica de argilominerais no Centro de Pesquisa da Petrobrás. Boletim de geociências da Petrobrás, 2, 157-175.

Alves, D.B., Rodrigues, R., 1985. Influência das intrusões ígneas nos folhelhos devonianos da Bacia do Baixo Amazonas. Revista Brasileira de Geociências 15(2), 110-115.

Araújo, L.A., Triguis, J.A., Cerqueira, J.R., Freitas, L.C.S., 2000. The atypical Permian petroleum system of the Paraná Basin, Brazil. In: Petroleum systems of South Atlantic margins. American Association of Petroleum Geologists, 377-402.

Berman, R., 1988. Internally-consistent thermodynamic data for minerals in the system $\mathrm{Na}_{2} \mathrm{OK}_{2} \mathrm{O}-\mathrm{CaO}-\mathrm{MgO}-\mathrm{FeO}-\mathrm{Fe}_{2} \mathrm{O}_{3}-$ $\mathrm{Al}_{2} \mathrm{O}_{3}-\mathrm{SiO}_{2}-\mathrm{TiO}_{2}-\mathrm{H}_{2} \mathrm{O}-\mathrm{CO}_{2}$. Journal of Petrology 29, 445522. https://doi.org/10.1093/petrology/29.2.445

Brady, J.B., Cheney, J.T., Rhodes, L.A., Vazques, Green, C., Duvall, M., Kogut, A., Kaufman, L., Kovaric, D., 1998. Isotope geochemistry of Proterozoic talc occurrences in Archean marbles of the Ruby Mountains, southwest Montana, U.S.A. Geological Materials Research 1, 1-41.

Correa, L.M.S.A., Pereira, E., 2005. Estudo da distribuição das intrusões mesozóicas e sua relação com os sistemas petrolíferos da Bacia do Paraná. In: Simpósio de Vulcanismo e Ambientes Associados, Cabo Frio, 2005. Resumos expandidos, 21-26.

Costa, D.F.B., Santos, W.H., Bergamaschi, S., Pereira, E., 2016. Análise da geometria de soleiras de diabásio do magmatismo Serra Geral, por interpretação sísmica 2D, na região de Guaré, São Paulo, Bacia do Paraná, Brasil. Brazilian Journal of Geology 46, 605-615. http://dx.doi.org/10.1590/23174889201620160078.

Delpino, D.H., Bermúdez, A.M., 2009. Petroleum systems including unconventional reservoirs in intrusive igneous rocks (sills and laccoliths). The Leading Edge 28(7), 804-811. https://doi.org/10.1190/1.3167782

Dos Anjos, C.W.D., Meunier, A., Guimarães, E.M., Albani, A., 2010. Saponite-rich black shales and nontronite beds of the Permian Irati Formation: sediment sources and thermal metamorphism (Paraná Basin, Brazil). Clays and Clay Minerals, 58, 606-626. https://doi.org/10.1346/CCMN.2010.0580503

Dos Anjos, C.W., Guimarães, E.M., 2008. Metamorfismo de contato nas rochas da Formação Irati (Permiano), norte da Bacia do Paraná. Revista Brasileira de Geociências 38, 629641.

Euzébio, R.S., Reis, D.E.S., Brito, M.A.R.C., Bergamaschi, S., Martins, M.V.A., Rodrigues, R. 2016. Oil generation potential assessment and paleoenvironmental interpretation of Irati Formation (Lower Permian) in northwestern of Paraná Basin (Brazil). Journal of Sedimentary Environments 1(2), 254-267. https://doi.org/10.12957/jse.2016.23388
RESEARCH PAPER

Frey, M., 1987. The reaction-isograd kaolinite + quartz $=$ pyrophyllite $+\mathrm{H}_{2} \mathrm{O}$, Helvetic Alps, Switzerland. Bulletin Suisse de Minéralogie et Pétrographie 67, 1-11.

Galushkin, Y.I., 1997. Thermal effects of igneous intrusions on maturity of organic matter: A possible mechanism of intrusion. Organic Geochemistry 26(11), 645-658.

Girardi, V.A.V., Melfi, A.J., Amaral, S.E., 1978. Efeitos termais associados aos diabásios mesozoicos da Bacia do Paraná. Boletim do Instituto de Geociências, USP, 9, 47-55.

Hachiro, J., 1996. O Subgrupo Irati (Neopermiano) da Bacia do Paraná. PhD Thesis, Universidade de São Paulo, Brazil, 196 p.

Hoffman, J., Hower, J., 1979. Clay mineral assemblages as low grade metamorphic indicators: Application to the thrust faulted disturbed belt of Montana, U.S.A. In: Scholle, P.A., Schluger, P.K. (eds.): Aspects of Diagenesis. Society of Economic Paleontologists and Mineralogists Special Publication 26, pp. 55-79.

Holanda, W., Bergamaschi, S., Santos, A.C., Rodrigues, R., Bertolino, L.C., 2018. Characterization of the Assistência Member, Irati Formation, Paraná Basin, Brazil: Organic matter and mineralogy. Journal of Sedimentary Environments 3(1), 36-45. https://doi.org/10.12957/jse.2016.23388

Illgen, A.G., Heath, J.E., Akkutlu, I.Y., Bryndzia, L.T., Cole, D.R., Kharaka, Y.K., Kneafsey, T.J., Milliken K.L., PyrakNolte, L.J., Suarez-Rivera, R., 2017. Shales at all scales: Exploring coupled processes in mudrocks. Earth-Science Reviews 166, 132-152. https://doi.org/10.1016/j.earscirev.2016.12.013

Inoue, A., Velde, B., Meunier, A., Touchard, G., 1988. Mechanism ofillite formation during smectite-to-illite conversion in a hydrothermal system. American Mineralogist $73,1325-1334$.

International Centre for Diffraction Data (ICDD), International Centre for Diffraction Data-Pdf4+ Relational Powder Diffraction File. Available online: http://www.icdd. com/products/pdf4.htm, Accessed on 20 March 2018

Jaeger, J.C., 1959. Temperatures outside a cooling intrusive sheet. American Journal of Science 257, 44-54.

Jones, S.F., Wielens, H., Williamson, M.C., Zentilli, M., 2007. Impact of magmatism on petroleum systems in the Sverdrup basin, Canadian Arctic islands, Nunavut: a numerical modelling study. Journal of Petroleum Geology 30(3), 237256.

Li, X., Wang, Q., Zhang, W., Yin, H., 2016. Contact metamorphism of shales intruded by a granite dike: Implications for shale gas preservation. International Journal of Coal Geology 159, 96-106. https://doi.org/10.1016/j.coal.2016.03.016

Martins, V., Dubert, J., Jouanneau, J. M., Weber, O., da Silva, E., F., Patinha, C., Rocha, F., 2007. A multiproxy approach of the Holocene evolution of shelf-slope circulation on the NW Iberian Continental Shelf. Marine Geology 239 (1-2), 1-18. http://doi.org/10.1016/j.margeo.2006.11.001

Melo, B.G.V., Carvalho, I.S., Bertolino, L.C., 2018. Ambiente de sedimentação da Formação Brejo Santo, Jurássico Superior da Bacia do Araripe, Brasil. Anuário de Geociencias - UFRJ 41, 265-282.

Meunier, A. 2005. Clays. Springer, 472p. 
Milani, E.J., Zalán, P.V., 1999. An outline of the geology and petroleum systems of the Paleozoic interior basins of South America. Episodes 22(3), 199-205. https://doi.org/10.18814/epiiugs/1999/v22i3/007

Milani, E.J., 1997. Evolução tectono-estratigráfica da Bacia do Paraná e o seu relacionamento com a geodinâmica fanerozóica do Gondwana sulocidental. PhD Thesis, Instituto de Geociências, Universidade Federal do Rio Grande do Sul, $255 \mathrm{p}$.

Miranda, S.F., Cunha, P.R.C., Caldeira, J.L., Michelon, D., Aragao, F.B., 2016. The atypical igneous sedimentary petroleum systems of the Parnaiba basin: Seismic, well-logs and analogues. AAPG International Conference \& Exhibition, Abstracts.

Mizusaki, A.M.P., Thomaz Filho, A., 2004. O magmatismo pós paleozóico no Brasil. In: Neto, V.M., Bartorelli, A., Carneiro, J.C., Brito-Neves, B.B. (Ed.). Geologia do Continente SulAmericano: Evolução da Obra de Fernando Flávio Marques de Almeida. São Paulo, 28-292.

Moore, D.M., Reynolds, R.C., 1997. X-ray Diffraction and the Identification and Analysis of Clay Minerals. Oxford University Press, Oxford, 378 p.

Mullis, J., 1979. The system methane-water as a geologic thermometer and barometer from the external part of the Central Alps. Bulletin de Minéralogie 102, 526-536.

Neves, L.E., 1968. Estudo prático de argilas por difratometria de raios X. Boletim Técnico da Petrobrás 11, 123-135.

Pytte, A.M., Reynolds, R.C., 1989. The Thermal Transformation of Smectite to Illite. In: Naeser, N.D., McCulloh, T.H (Ed.). Thermal History of Sedimentary Basins. Spinger, New York, NY.

Santos Neto, E.V., 1993. Caracterização geoquímica e paleoambiente deposicional da sequência carbonato-pelítica superior do Membro Assistência, Formação Irati no Estado de São Paulo, Bacia do Paraná. MsD Thesis, Universidade Federal do Rio de Janeiro, Brazil, 203 p.
RESEARCH PAPER

Santos, R.V., Dantas., E.L., Oliveira, C.G., Alvarenga, C.J.S., Dos Anjos, C.W., Guimarães, E.M., Oliveira, F.B., 2009. Geochemical and thermal effects of a basic sill on black shales and limestone of the Permian Irati Formation. Journal of South American Earth Sciences 28(1), 14-24.

Schneider, R.L., Muhlmann, H., Tommasi, E., Medeiros, R.A., Daemon, R.F., Nogueira, A.A., 1974. Revisão estratigráfica da Bacia do Paraná. In: Congresso Brasileiro de Geologia, 28, Porto Alegre. Anais, 41-65.

Senger, K., Planke, S., Polteau, S., Ogata, K., Svensen, H., 2014. Sill emplacement and contact metamorphism in a siliciclastic reservoir on Svalbard, Arctic Norway. Norwegian Journal of Geology 94, 155-169.

Simoneit, B.R.T., Brenner, S., Peters, K.E., Kaplan, I.R., 1978. Thermal alteration of cretaceous Black Shale by basaltic intrusions in Eastern Atlantic. Nature 273, 501-504.

Thomaz Filho, A., Mizusaki, A.M.P., Antonioli, L., 2008. Magmatism and petroleum exploration in the Brazilian Paleozoic basins. Marine and Petroleum Geology 25(2), 143151. https://doi.org/10.1016/j.marpetgeo.2007.07.006

Wang, D., Lu, X., Song, Y., Shao, R., Qi, T., 2010. Influence of the temperature dependence of thermal parameters of heat conduction models on the reconstruction of thermal history of igneous-intrusion-bearing basins. Computers \& Geosciences 36(10), 1339-1344.

Wang, D., Song, Y., Liu, W., Zhao, M., Qi, T., 2011. Numerical investigation of the effect of volatilization and the supercritical state of pore water on maturation of organic matter in the vicinity of igneous intrusions. International Journal of Coal Geology 87(1), 33-40.

Weaver, C.E., 1989. Clays, muds and shales. Developments in sedimentology. Amsterdam, 556 p.

Whitney, G., and Northrop, H.R., 1988. Experimental investigation of the smectite to illite reaction: Dual reaction mechanisms and oxygen isotope systematics. American Mineralogist, 73, 77-90.

Winkler, H.G.F., 1976. Petrogenesis of metamorphic rocks. Berlim: Springer, $334 \mathrm{p}$. 